\title{
Cattle and its mythical-epic themes in Shahnameh, Garshasbnameh, Koushnameh, Borznameh, Bahmannameh and Banogoshasbnameh
}

\section{El ganado y sus temas mítico-épicos en Shahnameh, Garshasbnameh, Koushnameh, Borznameh, Bahmannameh y Banogoshasbnameh}

\author{
Nasrin Sharifzad \\ PhD Student in Persian Language and Literature, Islamic Azad University, Mashhad Branch, \\ Iran

\section{Mohammad Shah Badizadeh} \\ Department of Persian Language and Literature, Islamic Azad University, Mashhad Branch, \\ Iran

\section{Reza Ashrafzadeh} \\ Department of Persian Language and Literature, Islamic Azad University, Mashhad Branch, \\ Iran
}

*Correspondence

Email: NasrinSharifzad@gmail.com
Cite as:

Sharifzad, N., Shah Badizadeh, M., \& Ashrafzadeh, R. (2021) Investigation and analysis of color pragmatics in Beyghami DarabNameh. Propósitos y Representaciones, 9 (SPE1), e871. Doi: http://dx.doi.org/10.20511/pyr2021.v9nSPE1.871 


\section{Summary}

In Shahnameh and other epic poems, which reflect the myths, the life of primitive and ancient Iranian societies, animals and other animals are of great importance and go beyond their normal features and status. Myths that are truths of the thoughts and ideas of the first people, which are mixed with different stories and are expressed symbolically and cryptically. Epic events are usually the result of linking these myths to history .Among the animals, "cow" is one of the actors that is mentioned in Ferdowsi's Shahnameh and other epic poems, and has its own themes and themes. This article aims to examine the place of the cow in the myths and civilization of the past, as well as in the most valuable epic work, Shahnameh and five other epic poems (Garshasbnameh, Kushnameh, Bahmannameh, Banogshsabnameh and Borzoonameh) and the most important mythological themes. Extract, classify and analyze the epic and ritual of this animal. These themes are: lexical and symbolic meaning of cow, the place of cow in myths and ancient Iran, the relationship between creation and death of Kiomars with cow, cow relationship with human psyche and moon , Heroic Cow, Heroic Breeding, Sculpture or Composition, Gausser Stick,, Cow, Name of the Tower in the Sky, Cattle Totem.

Keywords: Cow, Shahnameh, myth-epic themes, epic poems.

\section{Resumen}

En Shahnameh y otros poemas épicos, que reflejan los mitos, la vida de las sociedades iraníes primitivas y antiguas, los animales y otros animales son de gran importancia y van más allá de sus características y estatus normales. Mitos que son verdades de los pensamientos e ideas de las primeras personas, que se mezclan con diferentes historias y se expresan de forma simbólica y críptica. Los eventos épicos suelen ser el resultado de vincular estos mitos con la historia. Entre los animales, "vaca" es uno de los actores que se menciona en el Shahnameh de Ferdowsi y otros poemas épicos, y tiene sus propios temas y temáticas. Este artículo tiene como objetivo examinar el lugar de la vaca en los mitos y la civilización del pasado, así como en la obra épica más valiosa, Shahnameh y otros cinco poemas épicos (Garshasbnameh, Kushnameh, Bahmannameh, Banogshsabnameh y Borzoonameh) y el más importante tema mitológico. Extrae, clasifica y analiza la épica y ritual de este animal. Estos temas son: significado léxico y simbólico de la vaca, el lugar de la vaca en los mitos y el antiguo Irán, la relación entre la creación y muerte de Kiomars con la vaca, la relación de la vaca con la psique humana y la luna, Vaca heroica, Cría heroica, Escultura o Composición, Palo Gausser, Vaca, Nombre de la Torre en el Cielo, Tótem de Ganado.

Palabras clave: Vaca, Shahnameh, temas mitos-épicos, poemas épicos.

\section{Introduction}

In epic tales, animals play the role of heroes. Among mythical animals, the value and importance of the cow in human life is such that rituals and beliefs have been narrated about it. It shows the presence of this animal in human life, and some have changed their nature by merging with a myth or story and have found a mythical, symbolic and mythical face. The most prominent references about this animal can be seen in epic works such as: Shahnameh, Garshasbnameh, Kooshnameh, Bahmannameh, Banogshsabnameh and Barzoonameh. Also, a brief description of these six epic works is given in this article.

\section{Problem solving}

Ancient texts are one of the most important sources to know the value of animals in the culture of ancient Iran, which can undoubtedly be used to understand the importance of animals by repeating their names in ancient texts or drawing their images in works of art, so that this The texts speak of the importance of animals and how they were treated in ancient Iran, and Iranians could use the physical and behavioral characteristics of animals to express their beliefs and give 
symbolic color to their ideas. Evidence left from ancient Iran shows the special place of cows in the minds and culture of the people of that time. Sometimes the cow is a symbol of power, fertility and awareness. The sanctity and honor of this animal is evident in epic poems and myths. The mythical-epic and ritual themes and themes of this animal in poems such as (Shahnameh Ferdowsi, Garshasbnameh, Koushnameh, Bahmannameh, Banogshsabnameh and Borznameh) show this issue. In this article, an attempt has been made to study Shahnameh and other epic poems and also according to folklore, various themes about cows have been extracted.

\section{Research history}

About the cow and its role in myth and with the characteristics that we have enumerated for it, a comprehensive research that examines its mythological-epic and ritual themes in epic poems such as (Shahnameh, Garshasbnameh, Kushnameh, Borzonameh, Banooshshsabnameh and Bahmannameh) has not been done. In this regard, we come across books and dissertations. Among the books that have been used in this research: Mahin Dokht Sedighian, the book of Iranian mythological-epic culture, Hall James, the iconographic culture of symbols in the art of East and West, Iranian mythological culture and Khosrow Gholizadeh, the book of animal mythology, The book of symbols is Jobs Gertrude (vol. 1) and ... The main question of this research is: What is the place of the cow in the mythical, epic and ritual dimension in the ancient, mythical past and in the epic systems mentioned?

\section{Research Methodology}

The present research has been expressed in an analytical-descriptive manner and the data collection in this research has been collected in a documentary and library manner, which has collected information on the subject by referring to books, articles and internet sites. Has been.

\section{Shah nameh}

Shahnameh by Hakim Abolghasem Ferdowsi Tusi, a poetic epic in the convergent sea of Mutman, has been deleted and has almost 60 thousand verses and is one of the largest and most prominent epic works in the world, which has been composed for nearly thirty-five years. The content of this literary masterpiece: myths, legends and history of Iran from the beginning to the conquest of Iran by the Arabs in the seventh century, which are summarized in four dynasties of Pishdadian, Kianian, Parthian and Sassanid and divided into three parts: mythical, heroic (epic). ) And historically divided. When the language of science and literature in Iran was Arabic, Ferdowsi revived and revived the Persian language by composing the Shahnameh. One of the important sources that Ferdowsi used to compose the Shahnameh was the Shahnameh of Abu Mansouri.

\section{Garshasb letter}

"The second great epic work (after Shahnameh) Garshasbnameh [composed by Abu Nasr Ali Ibn Ahmad] Asadi Tusi is the great poet of Iran in the fifth century AH ..." (Safa, 1384: 283) This poem is the story of Garshasb, the great hero of Sistan Jad It is the highest of Rostam; Garshasb is an Indo-Iranian mythological figure whose name and the oldest scattered news about his functions appear both in the Avesta letter and in the epic poems of ancient India (Sarkarati, 1387: 251). Asadi Tusi first deals with the lineage of Garshasb. And after mentioning Some of the events of his fathers' days retell the epic narratives of Garshasb and adorn his whole life with wonderful and wonderful events and adventures. This epic work is full of superstitions about Garshasb, and of course animals play a significant role in this poem.

Kushnameh is one of the national, mythological and heroic epics that the poet Iranshah Ibn Abi Al-Khair organized in the sixth century AH. This book is the story of Kush Pilgon, 
Zahak's nephew, who ruled China, the Maghreb and Africa for many years with power and oppression, and during this time he always fought and fought with the Jamshidians, but in the end, he practiced justice and godliness. Slowly This book contains a description of the characteristics of a number of mythological characters. The poet of Kushnameh, the sage Iranshah Ibn Abi Al-Khair, has arranged the system between the years 498 to $501 \mathrm{AH}$. Ferdowsi are similar in general, but with a deeper look we find that the poet did not make these events to imitate the events of Shahnameh, but like Ferdowsi has used the original written and oral sources.

\section{February letter}

Bahmannameh is an epic Masnavi about the events of the reign of Bahman, the son of Esfandiar, King Kiani, and his battles with the Rostamzal family. This work is over ten thousand verses that was composed by Iranshah Ibn Abi Al-Khair in the late fifth or early sixth century. (Afshari, 1997, vol. 4, entry of Bahmannameh) With the reign of Bahman, the Rostam family was sold and disappeared. He is a fusion of myth and reality. His other name is written in Shahnameh and historical sources of Ardeshir and historians sometimes equate him with Cyrus the Achaemenid and more often with Ardeshir Achaemenid. (Pirnia, 1386, J 2: 884). The exact date of the Bahmannameh order is also unclear, and scholars have said that it was in order in the fifth century

\section{Late fifth or early sixth century.}

Barzunameh is a great epic poem, composed by Shamsuddin Mohammad Kosaj, one of the poets of the eighth century, in which he tells the story of Borzoo (Sohrab's son), his wars and his performances in 4200 verses. Borzoo is the son of Sohrab, who lives in the mountainous logic of Shengan with his mother, Shahro. Afrasiab, who passes through Shengan with his army, which was defeated by Iran and returning to Turan, and sees Barzour as a strong and worthy young man, encourages him to fight Rustam by making many promises. Zoo accepts this offer and after learning the etiquette of war, he goes to Iran with the Turan Corps and, unknowingly, confronts his ancestor, Rostam, and during several battles, he is eventually captured by Faramarz. . Borzoo is sent to Sistan Fortress. After hearing the news of the child's capture, Shahro goes to Sistan and there, with the help of a robber, prepares the ground for Borzoo to escape from the fortress. Rostam is returning to Iran when Borzoo escapes and sees Borzoo on the way and the battle between them begins again. In this battle, Borzoi is defeated and his identity is revealed to Rostam, and war leads to peace and friendship.

The epic poem of Lady Gashsabnameh in the form of Masnavi, in the convergent sea of Mutman, about the heroism of "Lady Gashsab" or (Gashsab Banu) girl (Rostam) which was written in the fifth or sixth century following Ferdowsi's Shahnameh. Lady Gashsab's poem contains 1,032 verses and has no introduction. The symbolic name of Lady Gashnesb, meaning the owner of a male horse or a female heroine such as a male horse, is used in this story. At the beginning of this poem, Rostam entrusts the training of his son (Faramarz) to Lady Gashsab, and then the description of its heroism, especially "Lady Gashsab", who is referred to as Lady in the poem, follows. Lady Gashsabnameh, the only Persian epic poem whose protagonist is a woman. According to the main index, the stories and heroism of Lady Gashsab may go back to the ancient culture of the Iranian tribes. The remarkable point in this poem is that there are two aspects of Lady Gashsab's character; On the one hand, she is a beautiful, powerful and rebellious woman who fights with men, even her lovers, and on the other hand, she is a girl obedient to her father. Lady Gashnasb does not know the letter. Since in some versions, this poem is mentioned in one volume with Faramarznameh of the poem about Faramarz, son of Rostam, Karachi, it is probable that the poet of both poems is one person. (Karachi, Introduction 2003)

\section{The lexical roots of cattle}

The root of the cow in the Avesta is "go" gav, and the word go gav means bull, and the combination of go deeno-gava is used specifically to refer to a female cow. The word cow is often 
used in (gao in the Avesta) to mean bull and calf. The word also means "beneficial animals and livestock." In addition, in three cases, it refers to the mother earth and the psyche. In Avestan texts, in addition to the meaning of "cow" for the form gauu - several other meanings are given, (Gholizadeh, 2013: 189)

In Zoroastrian culture, the word "cow" is still found on a group of animal names, such as: buffalo, cow, goose, cow, boar, and buffalo, and this is the reason why the word in the Avesta was the name of a genus. The sheep, which today refers to the ewe, both male and female, was originally a "gospent" (sacred cow).

\section{Cows in mythology, ancient Iran and epic regimes}

In ancient Iran, the cow was considered the most useful of the four ends. The bull or Varza, which was responsible for farming and plowing, in addition to being the basis of nutrition, was considered a very valuable aid to humans in the agricultural life of that time. (Farhangs S. Atir, 2009, under the cow).

Ovagdat ovagdat »:» According to the narrations related to creation in ancient Iran, it was the fifth stage of creation in the creation of the animal world. As in the case of the creation of plants in mythology, we speak of the "all-seed" tree from which all plants are made, and in the case of animals, it was believed that a strong "ogdat" was the seed of all cattle and even some useful plants. Has with him. This cow was the only creature on earth and an animal, beautiful and strong, sometimes depicted as a bull and sometimes a female bull. Kiomers, like this cow, emerged from the dust, and they were both at rest for 3,000 years. When the evil demon reached the first cow, the cow fell ill despite Ahuramazda's efforts and eventually passed away. The cow's ghost (Goushurvan) asked Ahuramazda for the appearance of a man who supported the animals. Then each member of the first cow grew 55 kinds of healing plants and gained its glory from the first cow. From this a pair of bulls and females emerged, followed by two hundred and eightytwo pairs of each animal on earth.

There is no mention in the Avesta of the nature and manner of the creation of cattle and animals. But according to his servant, Hormoz created the cow on his right and Kiomars on his left. According to Bahar, Jupiter created the cow from his right hand and probably Kiomars from the rotation. (Bahar, 1375: 50)

Examining the evidence, we find that the creation of creatures from cows or primates is an ancient Indo-European index. Cow myths are the earliest remnants of several ancient IndoEuropean myths. First, the idea of the creation of creatures from the body of a giant creature originates from the story of the creation of the universe and has a history in the myths of many nations (Gholizadeh, 1392: 196) An early cow and an early human existed together before the beginning of the human world, and the world came into being from these two beings. (Christian Sen, 1985: 47).

\section{The Relationship between the Creation and the Death of Kiomers with the Cow}

In Persian mythology, the creation of Kiomers is associated with the emergence of the cow. Humans and animals are created in the same conditions and in exactly the same way, both are among the most important elements of creation and in a way the creation is completed with them. In his servant it is said about the creation of man and cow: "Kiomers on The left and the cow were created on the right of Jupiter. His distance from each other and also the distance from the water was as high as his own. Kiwmarth had eyes, ears, tongue and dryness. Jupiter created Kiomers from the earth with a cow. "He raised the seed of the people and the cattle from the light and green of the sky." (Farnbagh Dadgi, 1378: 41) Therefore, the creation of man and cow has taken place 
in the same conditions. This issue is also observed about the death of the two, so that the death of both occurs in the same way and in a similar situation. The cow came, the cow fell to the right hand towards noon, and Jupiter took the body and mirror (shape) of the cow and handed it to the moon. Then when he came to Kiomars, Kiomars fell to the left to noon, Jupiter took his body and threw it to the sun, because the cow was like the moon and Kiomers was like the sun "(Ibid: 6970) after the devil It destroys cattle and humans, an important event that brings the two closer. "The devil, with all his efforts, cannot lead to the complete destruction of man and cow, and the life of each is manifested in a different form." According to the Zoroastrian tradition, the first man and the first animal were created perfect and immortal, and as long as the devil gave them Invaded. His attack on Ormazd took place on the first of Farvardin at noon. The cow, who was more vulnerable, died first and died thirty days later. However, in the realm of meaning, their deaths were returned to begin again in life. The cow's semen was transferred to the moon and purified. New generations of animals emerged from it on the earth, and also from various parts of his body, various grains and medicinal plants grew "(Krasnovolska, 2003: 102-103). Also at the time of Kiomers' death," from the seed that went to the ground, They grew up for forty years, which was due to the prosperity of the world and the destruction of the court and the disability of the devil "

\section{Cow in Zoroastrianism}

In Zoroastrian times, the cow was considered a symbol of wealth and possessions. For this reason, Art, the angel of wealth, takes refuge in cows, and for this reason, with the adjective, it is called "soothing" and "joyful": "Until the Holy Father created you to make us happy cows. That sedative for this cow pasture created Armiti, so he, O Ahuramazda, also inquired with Vahumaneh. The Joyful Cow is also mentioned in Yasin 50 (verse 2): "O Mazda, will the joyful cow be given to one who wishes to be given a piece of pasture?" In this verse, the word "cow" is a metaphor for reward. Lent is fasting and forgiveness is Minoan It is not unlikely that since the time of Zarathustra, in the eyes of the people, a connection has been made between various mythical and symbolic beliefs with the grief and glory of the cow. The word gauu was not only a neutral general name with no grammatical value, but it was as mysterious or symbolic as it was glorious, and from ancient times it played an important role in the mythical and religious ideas of the Aryans. It is difficult to cover the familiar and to connect one's intentions with the divine and religious teachings. (Gholizadeh, 1392: 193)

\section{Cows in the ritual of Mehr}

The myth of the first cow remains in the religion (seal worship) and the Manichaean religion, with the difference that in the religion of Mehr, the first cow was a demonic creature with whom Mehr fought in a special order and After overpowering him, he grabbed him by the nostrils and plunged a sticker into his side with his hand. At this moment, all the plants and all kinds of animals emerged from the organs and blood of cows. (Myth Culture, 44, below the cow). In the ritual of Mehr, sacrifice is one of the beliefs of this great ritual. In the ritual of Mehr, Mitra or Mehr speaks of sacrificing a cow in the act of creating company, and according to this narration, the victim's belief in Mehr worship is formed. Statues of the Mithraic religion show Mitra kneeling and pointing to a bull in the back, while inserting a dagger into the cow's nest. Some of these traces of Gavner's tail end in three grain stalks and in one of them The stalks of grain protrude from the dagger wound instead of blood. Such works indicate that the bull, whose slaughter seems to be one of the main features of Mithraism, was at least one of the aspects of the spirit of grain "(Fraser, 2003: 525 and 526) Izadmehr by sacrificing "In this ritual, the victory of the first Berga seal is one of the necessities of the winter revolution through the dominance of light and darkness and heat and spring over cold and It has been winter "(Estakhri, 1381: 89) The resemblance of this cow to a unique cow is a noteworthy point of this ritual; All kinds of herbs and medicines are created after the death of a single cow; Let life and life flow in the body of the seal. "When the seal sacrificed the cow, then a strange miracle happened; From the body of the dying victim came all the useful herbs and plants, and the earth was covered with grass. From his forbidden kernel 
grows wheat which is used for food and from his blood grows from rose from which holy drink is obtained (Christian Sen, 1377: 126) In the section on the necessity of the presence of cows in Mithraism, this point can also be reached. He found that with death and sacrifice, one of the principles of creation, life and life is re-formed. The ritual of sacrifice symbolically leads to the expansion and development of human life, as well as the attainment of his desire for immortality. In fact, sacrifice and redemption are a means of gaining access to manna in the relationship between human beings and spirits. However, the sacrifice causes a person's longevity. (Zumradi, 2003: 327)

\section{Cow as a symbol}

Awareness, energy, producer, fertility, sustainability, tolerance, capability, wealth, fertility, creativity, usefulness, naivety, power, patience, work, agriculture, heat, great sunshine, ignorance, coldness, pride, etc. are symbolic meanings. Who are cows.

Cows have long had common symbols in different cultures such as power, fertility and fertility due to their colorful role in human livelihood, including plowing, lactation, use of meat and skin.

The bull has the symbol of protection and guarding of old statues. Its example can be seen in the eastern gate of Persepolis. The sign of the bull with the name of Thor is one of the constellations and promises the revival of spring. The bull symbolizes the masculine principle. And is the force of childbirth. It is also a symbol of fertility and a symbol of the earth.

In the cult of love and Mithraism, killing a cow was a symbol of liberation from self and lust, as if it was done to unite with the god of love.

After the advent of Zarathustra, killing and sacrificing cows was forbidden as a religious custom, and Zarathustra did not allow the killing of cows except as a necessity and as food. Also, eating beef and other living things was forbidden on some days of the year. In Persepolis, cows and lions symbolize the moon and the sun (summer and winter), and the victory of the lion over the cows symbolizes the end of winter and the rebirth of nature. Due to its resemblance to the crescent moon, the cow was always a symbol of the moon. (Abdullahi, 2002: 48).

Bahram must fight with the cow, which is a symbol of wisdom, on the lion, which is a symbol of kingship, power and anger, and which is in the possession of his father, and thus prove that he is worthy of succeeding Fereydoun, who also laughs with the staff of wisdom. Destroyed. Prominent examples of the connection between cattle and intrinsic wisdom are in the story of Bahram Gour and the woman of Palizban. 1389: 217).

In Kushnameh, Gavan mentions the symbol of ignorance:

Fereydoun became so bad with knowledge that he considered people as cows

(Kushnameh: 398, bit 4680)

\section{Cow as a common name}

The same cow with a steering wheel, the same greyhound with a gem

(Shahnameh, vol. 1:46, verse 79)

He stewed cattle, donkeys and sheep to the market and killed people

They named Kushan the city named after Kushan Joyandeh Kam

(Kooshnameh: 499, bit 6663-6664)

The farmer's cow was the black cow always badly happy year and month

(Bahmannameh: 459, bit 7793) 
Cow is the name of the tower in the sky

In Shahnameh, the reign of Kaykhosrow:

They put their heads in front of him on the ground and everyone sang one by one

That we are slaves and the king trusts the head of the cow to trust the fish tower

(Shahnameh, vol. 3:12, verses 162 and 163)

There is no land left in the army, it is expensive on the back of a cow

(Lady letter letter: 146, bit 740)

The pure world burned with fire so that the basement of cattle and fish burned

(Garshasbnameh: 376, bit 96)

When the sun rose, the head came from behind the cow and roared

A world to a kingdom all over Merast, from the head of a cow to the tower of my fish

(Shahnameh, vol. 1: 556, verses 702 and 703)

Cow Totem

In general, the totem is a harmless animal or a dangerous and terrifying animal that has a special relationship with the whole group and rarely a plant or one of the plants. Nature's (rain, water) totems are placed. The totem is first and foremost the ancestor of the group, and secondarily the guardian and benevolent spirit who sends messages through the unseen voice, and while he is dangerous to others, he recognizes his children and does not bite them. There are different types of totems: a- Totem of the tribe that is passed from one generation to another, b- Totem for one sex, ie totem belonging to all members of the tribe who are the same sex, female or male, and other members of the tribe who are of the other sex, Are not partners in this totem, c- The totem of a person who belongs to a person and is passed on to his descendants (Freud 1349, J 7: 141) Totemism is a matter of primitive human history, but it may not be certain that all primitive peoples believed in totems: "Animals and plants did not appear only in the role of tribal totems, but perhaps as individuals who were themselves an animal or plant principle. They knew that they may be members of tribes and families that did not have a totem. (Bahar, 2002: 490)

Cattle are among the totem animals that play a major role in Avesta and ancient Iranian myths. This animal is a common totem of Indo-Aryan culture and is one of the strongest domestic animals that is found in ancient Iran, Middle Persian and Sanskrit. (Hassan Doust, 2014, vol. 4: 2336) The value and sanctity of cattle in ancient Iran with the type of agricultural life (Animal husbandry is related to them. (Christian Sen, 1998: 53) In addition to being the basis of nutrition, cattle were a very important help for humans in the agricultural life of that day and was responsible for farming and plowing. Dadvar and Mansouri, 2006: 61) The reference to the types of cows and related activities in Iranian mythology and Indo-European culture, has led researchers to believe that farming is the main Indo-European activity first and foremost than cultivation. (Bahar, 1389: 386) This type of pastoral and agricultural life, the sanctity of the cow and the totem of this animal is more visible in the minds of Iranians. In Avesta, greetings are sent to pure and virtuous cows. It is fertility. And it is related to water, rain and rain, and in other narrations, woman has replaced these elements, and for this reason, in some myths, the hero fights with the dragon, the hero releases water, cows or women after killing the dragon, and so on. Existence becomes the destruction of famine and drought. (Mokhtarian, 1389: 222 and 227).

Another reason for the sanctity and value of the cow in Iranian mythology stems from the connection between the cow and creation; According to Zoroastrian belief, the unique cow created is the first creation, Ahura Mazda and the symbol of the universe and the creation of water and earth and the first manifestation of material creation (Kazazi, 3851: 291). According to a very ancient Indo-European myth, the gods initially sacrificed a marvelous creature that was sometimes thought of as a giant and sometimes as a cow; They made it from different parts of the body and different parts of the world, such as: sky, earth, water, plants, etc. In Persian mythology, this creature is a cow (uniquely created). According to an older tradition, the seal of this cow is sacrificed in order to be created from its components. According to Bandheshan, a demon kills it. According to Bandehshan, when the only created cow died, its sperm went up to the base moon and was refined there, from which a pair of bulls and females were created, which is the offspring 
of all animals; Fifty-five types of seeds and twelve types of plants grew from his brain, which was scattered on the ground. (Dadgi, 2006: 78).

The totem of the cow is also seen in Persian myths in the relationship between the cow and the Fereydoun family; In Fereydoun's genealogy, the suffix cow is found in the names of all his ancestors. (Ibid: 149) Also, the fact that Fereydoun was born at the same time as the birth of a cow named Barmayeh and that he was breastfed and raised with that cow are all reasons why he is a totem It is a family. Gauss Fereydoun's wand with which he goes to war with Zahak is another sign that this animal is a totem. Of course, Gaussar's rod is not only for Fereydoun; Rather, the mace is an Indo-Iranian weapon that, as a special weapon of the torpedo god, is a symbolic symbol of thunder and lightning, by which the cosmic dragon is seen. (Sarkarati, 1378: 119) This Iranian ritual weapon is more in the form of a cow. And most of the Iranian warriors have such a mace ... Zoroastrian priests wore the Gaussar Mehr mace as a symbol of war and struggle with the forces of evil. (Kazazi, 2007: 92 and 93).

According to the narration of Kushnameh, a person named "Bermain", the minister of selectivity, who can be the modified form of a cow based on Shahnameh, raises Fereydoun (Iran Shan Ibn Abi Al-Khair, 1998: 384). Kamdad, the minister of Abtin, after testing Sarkat and Bermain, entrusts the upbringing of Fereydoun to them (Ibid: 385). Elsewhere it is mentioned that in the words of the common people, the breeder of cattle, who breeds Fereydoun, is the same cow that breeds Fereydoun with its knowledge and teaches astronomy to him with a throne like a zigzag (Ibid: 398). Bit 4675).

Thus said every man who had sucked a cow from him (Kooshnameh: 398, bit 4675). In Garshasbnameh, the sanctity and honor of the cow is also seen; Where Mehraj Shah, in appreciation of Garshasb's efforts and wars against the enemies, presents a statue of a cow (Asadi Tusi, 1975: 197) and offers him sixteen thousand oxen and a thousand golden horses. : 200, 201) Also, the worship of cows in this system and the killing and eating of the meat of this animal from the Indo-Iranian tribes, shows that it is a totem among the Iranians. (Ibid. 169 and 196) The taboo of animals and the prohibition of killing and eating them , The core and main axis of the berry It forms the mism (Freud, 1342: 282) and the life of each member of the tribe depends on the life of these animals and plants; Therefore, I never contaminated my hand with the blood of such a conspiracy (Samadi, 1988: 1415) and they always tried to preserve it.

The belief that the earth is on the horn of a cow and another belief that shows the sanctity of the cow and the high value of this animal among the Indo-Iranian tribes. Signs of this belief can be seen in most of the epic poems. (Banoo Gashsapnameh, 2003: 110 and 120)

In Shahnameh, the character of Fereydoun is closely related to the cow and is considered the totem of Fereydoun's family.

Fereydoun is raised by a wonderful cow named Barmayeh:

"Wise Mam Fereydoun Cho saw. Which hit his couple so badly

Frank was a bad name and auspicious. He was full of love for Fereydoun

Full of hot tired times. Pouyan went to the meadow

Where was the infamous cow? Which should have been on the tension

To the guardian of that meadow. It roared and shed blood

Cain said to the infant. I once had a wife

Waresh's father is acceptable to his mother. And feed this cow to the milk

(Shahnameh, vol. 1: 58, verses 123-129)

This legendary cow was born at the same time as Fereydoun:

"The Sepehr Battalion went all over the place. Ram with Afridon to Mehr

The same cow was named after him. Gavaran Vera was the highest base 
The mother was separated from the male peacock. To every hair, a new color "

(Ibid: 57)

Fereydoun's brother is the same name as the cow that raised Fereydoun as a child:

His two brothers were two Farrokh Hamal, both of whom were more free for a year

One of them was Kianoosh, the other name was Barmayeh Shadkam. "

((Ibid: 65

Existing heroic cattle

In Ferdowsi's Shahnameh, this concept has been used in several ways to cultivate his stories, and in the story of Zahak and Fereydoun, it has been mentioned as a heroic animal. In this story, when the tyrant Zahak Abtin kills Fereydoun's father, Frank, the wife of Viba, his son Fereydoun, goes to the guard of the meadow where the cattle graze and says in an allegory, "Save this child for a while:

The worshiper of the grove and the cows and the hawks gave such an answer to the pure brain

Because I am a servant in front of your child, I worship your advice

At the age of three, he woke up from that awake lion cow

(Shahnameh, vol. 1: 63, verses 131-133)

Gaussian Storm

In the Shahnameh, in Bahram's conversations with the elders about his race, which is from the descendants of Jamshid and Fereydoun, he causes the Gausser to strike from now on. On the other hand, according to the mythological roots, this battle is a battle of wisdom and anger. "Bulls are the oldest symbol of wisdom, equal to the wisdom of the Sushyants." Therefore, wisdom can also be manifested in the body of a cow, which is a symbol of human wisdom "(Akbari Mafakher, 1392: 121), an example of which is the death of a cow and the demonic domination of Zahak. The women's head crushes and declares sovereignty again. In addition to transferring Farah Jamshid to Fereydoun, Barmayeh cow is also responsible for transferring Jamshid's wisdom to Fereydoun "(Ibid: 127), which is transmitted through Fereydoun's cow milk. Bahram is an example of the ideal kings of the quasi-historical part of the Shahnameh. With the Gausser wand, which is a symbol of wisdom, he plays the same role that Fereydoun needs. Just as Fereydoun destroys evil, ruin, and irrationality with the Gaussian mace, so he sits on the throne by striking the lion on the head, which is a symbol of the past, and removing the crown, which is one of the symbols of power. To reveal. According to Michael Berry, Bahram's weapon is similar to Inder's weapon: which Sanskrit Vajreh, the Avestan language in Iran, is called Vazreh and modern Persian is called Garz. It becomes a Gaussian stick, which is the very embodiment of God, because it solves the enemy "(Barry, 2006: 92-93)

Fereydoun's mace with which you laugh is also Gausser:

Head with this cow stick. Knock neither forgiveness logo nor seal

(Shahnameh, vol. 1: 70)

Of course, Gausser's mace is not limited to Fereydoun. The mace of war is an Iranian ritual tool, mostly in the shape and form of a cow, and Iranian heroes often have such a mace.

Esfandiar and Sohrab are Bahram Gour Garzshan Gausar.

The enemies of Iran are not exempt from this Gausser stick:

General was proud of Camus, who was with Lashkar and Peel and Kos

You got angry because the drunken elephant was holding a cowboy stick

(Shahnameh, J 4:42)

And from there, his father grabbed Gausser's wand

(Shahnameh, vol. 3: 74, verse 763)

The letter also mentions the head of a cow and the body of a cow:

One of the cowboy sticks attacked him like a drunken elephant

(Letter: 141, bit 2130)

When the boiling sea comes, Gausser's rod is cut on his head

(Letter: 261, bit 1703) 
Zoroastrian priests wore the Gaussar seal as a symbol of war against the forces of evil. In Shahnameh, the picture of Farhad Gaumish's flag is:

Darfashi, where is the body of the IRGC buffalo from behind and the spearmen from before?

You know that Shohreh Farhad is right as if he is right except with Sepehr

Shahnameh, J 4: 42

In Garshasbnameh, the flag of Gaupiker is also mentioned:

The yellow shield and the purple shield are cut from the cowboy

(Garshasbnameh: 101, verse 11)

\section{Behavior in the form of a cow}

The meaning of the representation or transformation of the change of appearance and structure and the legal basis and identity of a person or thing using supernatural force This seems unusual in any period and time. In this case, the person or object changes from one form to another and finds a new body, the appearance of which may be formal, apparent and tangible, or undergo fundamental changes in the institution and the latent, gaining new power or powers. Which he did not have before and as a result, although it is basically the same as before, a new transformation and change has been created in his face and heart that has found a new form and special and different actions (Rastegarfasaei, 2004: 43-44).

This theme about the cow is not very prominent in epic poems. The only example of this is mentioned in Garshasbnameh. Creatures that have a strange temperament - half human, half horse One to the head of a cow and the whale to the other

(Garshasbnameh: 161, verse 6)

\section{Moon and cow}

According to mythology, the cow is associated with the moon. In fact, the cow is a symbol of the moon (Bahar, 1998: 180). The semen of the first cow is refined in the moon. That is why the moon is described with the adjective (cow face) in Avestan texts and "sheep seed" in Pahlavi texts. Always after the death of any animal, the psyche goes to the moon and after being refined, it joins the gourd (beneficial animal psyche). And on the seals obtained from Susa, the importance of the cow's connection with the moon is seen more. The cow kills the carousel of the moon god, and the fertility attribute attributed to the moon is one of the characteristics of the cow. There is a symbolic relationship between a woman and a cow. In excavations to the first millennium BC, the image of women inside the ring of the moon is seen and a cow guards this ring (which is the symbol of the moon). (Samadi, 1988: 23) In a kind of moon, the female weight of all three symbols of fertility Are considered. In India, in the fourth month of pregnancy, a pregnant woman sits on the skin of a bull by the sacred fire, and the couple pragapatis, the server of the creatures. The moon is invited like a celestial or spiritual cow to be present in human reproduction. This is where we again remember the "moon containing the cow's seed" in the Avesta. In Slavic mythology, the cow is associated with the moon and the sun.

From time immemorial, the horns of a cow have been likened to the crescent moon. Gaussian statues that are always associated with the worship of the mother's moon (= moon). They are abundant in the Neolithic period (and reminds the reader of the statue of Fereydoon's cow stick). (Gholizadeh, 2013, 202).

.Later in the Sassanid era, the role of the moon god, who rides on his wheel and four cows move on his wheel, can be seen on the cup. (Samadi, 1988: 95) In Islamic history, the relationship between the moon and the cow has been mentioned. In the works of Al-Baqiyah, on the night of the 16th of January, the day of Mehr, which is a Persian holiday, Biruni says: "The reason why this day is celebrated is that the country of Iran was separated from Turkestan on this day and the 
cows that the Turkestanis They had plundered, the Turanian goose was taken back ... It was on this day that Fereydoun was weaned, and it was on this day that Fereydoun rode on the cow, and on the night of this day in the sky a cow of light whose horns He is made of gold and his feet are made of silver and he pulls the moon wheel, the hour is revealed, then he disappears and hides, and whoever manages to visit him, his prayer will be answered at the hour he looks at him. At night, the ghost of a white cow can be seen on the great mountain, and if this cow calls twice, it is a great year, and if it calls once, it will be a drought. "(Biruni, 1363: 346).

\section{Cattle and human psyche}

According to Bandheshan (p. 130), a Minoan dog is standing on Chinodale. A cow and a woman are present when they take the psyche for statistics. These women and cows come to greet the psyche in the past. If this psyche belongs to a bad person, the cow will look so dry and terrible that it will take the psyche away. She looks dry and fat and looks like the old lady of Gondbo, and if the psyche belongs to a charitable person, it is a fat and plump cow from which the psyche is perfect and the woman looks like a beautiful and fragrant girl. The cow and the maiden symbolize the mental actions of the past. The cow becomes a psychic guide to the realm of the dead, and apparently stays in the same Chinodale to welcome the other souls of the dead. Maybe this cow can be considered the same month (. (Gholizadeh, 1392: 206)

\section{Conclusion}

From what has been said in this research, it follows that the cow has always been considered a sacred and valuable creature in mythology. Evidence left from ancient Iran shows the special place of the cow in the minds and culture of the people of that time and Sometimes this animal has been a symbol of the moon, fertility and power and is associated with water, rain and rain. The motif of cow about the epic is not very prominent in epic poems, and only in Garshasbnameh do we encounter this motif. The totem footprint of this animal is common to Indo-Aryan and ancient Iranian culture. The totem of the cow is seen among Persian myths, in the relationship between the cow and the Fereydoun family. Cow as a symbol of power, fertility and wisdom, has always been considered and the use of different names, themes and mythical, epic and ritual themes of cows in Ferdowsi Shahnameh, Garshasbnameh, Kushnameh, Bahmannameh, Banooshsabnameh and Borznameh It shows this.

\section{References}

Estakhri, Parvin (1381). "Mithraism", History (Association Letter), Vol. 7, 160-150.

Akbari Mafakher, Arash (2013). "Gurani Narration of the Death of Shah Jamshid Tree", Proceedings of the Shahnameh Millennium Conference, May 24 and 25, by Mohammad Jafar Yahaghi, Tehran: Academy of Persian Language and Literature Publishing, 152160

Asadi Tusi, Ali Ibn Ahmad (1382). Garshasbnameh, edited by Habib Yaghmaei, edited by Parviz Yaghmaei, Tehran: Book World

Afshari, Mehran (1376) together Nnameh, Entry of the Encyclopedia of the Islamic World, Volume 4, Tehran, Encyclopedia Foundation of the Islamic World.

Iran Shah Ibn Abi Al-Khair (1370). Bahmannameh, edited by Rahim Afifi, Tehran: Scientific and Cultural Center of the Great Islamic Encyclopedia (1998) Koushnameh, by Jalal Matini, Tehran: Elmi.

Banoogshsabnameh (1382). Introduction, correction and spiritual explanation of Karachi, Tehran: Institute of Humanities and Cultural Studies.

Barry, Michael (1385). Interpretation of the seven military bodies, translated by Jalal Alavinia, Tehran: Ney Publishing 
Spring, Mehrdad (2002) From Myth to History, Tehran, Cheshmeh (1389). A Study in Iranian Mythology, Tehran: Agah, Eighth Edition

Biruni, Abu Rihan (1363). The rest of the works, translated by Akbar Danasersht, Tehran: Amirkabir Publications, third edition.

Pirnia, Hassan (2007) Ancient Iran, Tehran, Narmak

Hassan Dost, Mohammad (1393). Etymological Dictionary of Persian Language, Volumes 1 and 4, Tehran: Academy of Persian Language and Literature, Second Edition.

Dadgi, Farnbagh (1369). Bandesh, Reporter: Mehrdad Bahar, Tehran: Toos, Second Edition.

Dadvar, Abolghasem, Mansouri, Elham (2006). An Introduction to the Myths and Symbols of Iran and India in Ancient Times, Tehran: Kalhor Publications.

Rastegarfasaei, Mansour (2004) Sculpture in Mythology, Tehran, Institute of Humanities and Cultural Studies.

Zumradi, Homeira (1382). Comparative Critique of Religions and Myths, Tehran: Zavar.

Sarkarati, Bahman (1999) Shadows Hunted, Tehran, Qatreh Publishing.

Samadi, Mehrangiz. (1367). The moon in Iran from the earliest days to the rise of Islam, Tehran: Scientific and Cultural Publishing Company

Safa, Zabihollah (2008) Epic poetry in Iran from the oldest historical period to the fourteenth century AH, Tehran, Ferdows.

Abdollahi, Manijeh (2002) Dictionary of Animals in Persian Literature, Volume 2, Tehran, Researcher.

Ferdowsi, Abu Ghasem (2007) Shahnameh, 8 volumes, by the efforts of Jalal Khaleghi Motlagh, Tehran, the center of the great Islamic encyclopedia.

Freud, Sigmund (1349) The Psychoanalysis of the Future of an Idea, translated by Hashem Razi, Tehran, Kaveh.

Fraser, James George (1382). Golden Branch (Research in Magic and Religion), translated by Kazem Firoozmand, Tehran: Agah

Gholizadeh, Khosrow. (2013). Encyclopedia of Animals and Related Terms, Tehran: Parseh Book.

Krasnovolska, Anna (1382). Some key figures in the Iranian mythology, translated by Jaleh Motahdeen, Tehran: Varjavand.

Kristen Sen, Arthur (1353). Harmful creation in the Iranian narrative, translated by Ahmad Tabatabai, Tabriz: Institute of Iranian History and Culture.

Kazazi, Mir Jalaluddin (85). Ancient Letter, Vol. 1, Tehran: Samat, Fifth Edition Farghdani, Kobra (1386). "Totem in the stories of Shahnameh", Quarterly Journal of Language and Literature, No. 34, 85

Kosaj, Shamsuddin Mohammad (2008) Barznameh [Ancient Section] Introduction, Research and Correction by Akbar Nahvi, Tehran, Written Heritage

Mokhtarian, Spring (1389). An Introduction to the Mythical Structure of the Shahnameh, Tehran: Ad Publishing

Yahaqi, Mohammad Jafar (1375). Culture of myths and fictional allusions in Persian literature. Tehran: Soroush. 